\title{
Impact of Improved Rice Variety on Productivity Among Smallholder Farmers in Ghana
}

\author{
Edward Tsinigo $^{1}$, Kwasi Ohene-Yankyerah ${ }^{2}$, Simon Cudjo Fialor ${ }^{2}$ \\ ${ }^{1}$ Innovations for Poverty Action, Accra, Ghana. \\ ${ }^{2}$ Department of Agricultural Economics, Agribusiness, and Extension, Kwame Nkrumah University of Science and Technology, Kumasi, Ghana.
}

A R T I C LE IN F O

\section{Research Article}

Received 24 September 2016

Accepted 15 December 2016

Keywords:

Improved rice variety

Unimproved rice variety

Productivity

Cobb-Douglas production function.

*Corresponding Author:

E-mail: delustrous@yahoo.com
Structural change \begin{abstract}
A B S T R A C T
Advancement in agricultural technologies is seen to result in the shift in production functions. The study was conducted to establish the impact of the improved rice variety on productivity in the Ejura-Sekyedumase and Atebubu-Amantin Municipalities of Ghana. The study was based on the survey of 208 rice farmers using a three-stage stratified sampling method. The study used a structured questionnaire to collect inputoutput data from the rice farmers. Data were analysed using the Cobb-Douglas production function. The study found that the technical change associated with the introduction of the improved rice variety was of the non-neutral type. Further, the adoption of the improved rice variety has increased rice productivity by about $46 \%$ for the adopters. The main determinants of productivity for the adopters were seed, land, fertiliser, herbicide, and education. Productivity among the non-adopters was positively influenced by seed, land, herbicide, and fertiliser. The study concluded that the improved rice variety has superior yield advantage. The study recommends for the simultaneous promotion of improved rice varieties and their recommended inputs to increase rice productivity.
\end{abstract}

\section{Introduction}

Rice plays a critical role in the socio-economic development goals of countries. Rice is the most important staple food for a large part of the world's human population (FAO, 2006). Further, rice is the grain with the second-highest worldwide after maize (FAO, 2006; MoFA, 2009). Thus, rice is a key commercial food product and requires a more holistic approach to its production, management, and marketing in a manner that leads to poverty reduction. This view has been explicitly acknowledged in the earlier report of FAO (2004). The FAO (2004) alludes to the value of rice in contributing to hunger eradication, poverty alleviation, national food security and economic development through the improvement in the productivity of its systems.

In Ghana, total rice consumption is about 500,000 tons, of which more than 350,000 tons $(70 \%)$ costing over US\$ 600 million are imported (Government of Ghana, 2009). Conversely, domestic production accounts for less than $30 \%$ of the total supply and is increasing at a very slow rate. Thus, roughly 150,000 tons of rice consumed in this country constitute total domestic production. The huge amount of hard-earned foreign currency spent on rice import in Ghana is a potentially very risky and unsustainable situation. This requires a pragmatic paradigm shift in policy directive aimed at channelling this enormous amount into investing in the development of the domestic rice sector. In addition, the increased demand for rice globally, Africa, and Ghana, in particular, implies that more efforts are needed to increase the productivity of rice. The development of high yielding rice varieties is thus pivotal in achieving this food policy objective as well as ensuring food security and reducing poverty.

The World Bank (2008) identifies the agricultural sector as a necessary tool for sustainable development, poverty reduction, and a reliable source of self-food sufficiency for the Sub-Sahara Africa. Therefore, with increasing world population growth, agricultural productivity provides the impetus for sustaining human survival through enhanced food security. Agricultural productivity increases are also a vital prerequisite for sustainable economic development (O’Donnell, 2010). Such productivity increases benefits not only the direct employees in the sector but also benefits employees in other sectors through reduced food prices, more stable food supply and increase wage (OECD, 2006). Thus, Fan et al. (2000) assert that higher total factor productivity is desirable as it implies higher output from the application of technology, better utilization of resources, and a reduction in poverty in rural areas. 
Perhaps the most important source of agricultural productivity increases is technical change and improved varieties, in particular (Poulton et al., 2006; Hussain and Perera, 2004). Existing studies on the positive impact of technical change through improved varieties on productivity are well documented (Shideed and Saleem, 2005; Nin et al., 2003). Improved crop varieties increase output by either increasing outputs from the same inputs or maintaining the same output from reduced inputs (Adewuyi, 2006; Oni et al., 2009). Consequently, crop breeders, researchers, and policy-makers are confronted with the challenge of continually introducing improved and new crop varieties to address low productivity of crops. One such success story is the development of the New Rice for Africa (NERICA) as an alternative option to increase rice productivity within the Sub-Saharan African countries.

The success story of the improved variety has been reported in several countries in terms of increased productivity gains. Reported yields in West Africa were about $2500 \mathrm{~kg} \mathrm{ha}^{-1}$ with low use of inputs and yield of $5000 \mathrm{~kg} \mathrm{ha}^{-1}$ or more with the prudent fertiliser use, similarly, average yield of $2200 \mathrm{~kg} \mathrm{ha}^{-1}$ in Uganda (Kijima et al., 2006), $3500 \mathrm{~kg} \mathrm{ha}^{-1}$ in Guinea and an additional yield gain of 0.14 tons $\mathrm{ha}^{-1}$ in the Gambia (Dibba, 2010; JICA, 2006) have been widely reported. In fact, high yield gains between 3000 to $6000 \mathrm{~kg} \mathrm{ha}^{-1}$ under rain-fed uplands have equally been reported (Zenna et al., 2008). These studies clearly suggest that the improved variety has the superior yield advantage on farmers' rice field. Evidence of productivity impacts of the improved rice variety appears to be non-existing in Ghana. This study investigates the magnitude of the impact of the improved rice variety on the productivity of rice and the determinants of such productivity gains among the adopters and non-adopters.

\section{Materials and Methods}

\section{Data and Sampling Method}

A cross-sectional survey was conducted in the EjuraSekyedumase and Atebubu-Amantin Municipals of Ghana. These two municipalities had a high concentration of both adopters and non-adopters of the improved rice variety. A three-stage stratified random sampling method was used to select 216 rice farmers from the two Municipalities. This method was chosen due to its ability to ensure a high degree of representativeness by providing the elements with equal chances of being selected (Babbie, 2007). The first stage involved selection of three operational areas from each of the Municipalities (totalling six) using simple random sampling method. The simple random sampling was used to ensure that every rice farmer had the chance to be included in the study. The six selected operational areas were Aframso, Samari Nkwanta, and Dromankuma in the Ejura-Sekyedumase Municipality, and Atebubu Central, Amantin, and Fakwasi from the Atebubu-Amantin Municipality. Next, two rice growing communities were randomly sampled from each of the selected operational areas. This yielded 12 rice growing communities from the two municipalities.

The final stage involved the selection of 18 rice farmers from each of the selected communities based on the strata - adopters and non-adopters. In each stratum, nine rice farmers were randomly sampled. The random sample of the rice farmers was done based on a compiled list of rice farmers in each rice growing the community by the agricultural extension officers. This totaled 216 rice farmers. However, due to missing data on input use of 8 rice farmers, only data on 208 rice farmers were used. These comprised 103 non-adopters and 105 adopters of the improved rice variety. Input-output data were collected for the major season of the 2012 rice production season using a structured questionnaire. The structured questionnaire was used to collect information on inputs such as land, seed, fertiliser, herbicide; yield of rice production as well as the demographic characteristics of the rice farmers. Data were collected by the researcher with support from agricultural extension agents.

\section{Empirical Model}

The study used the Cobb-Douglas production to estimate the impact of the improved rice variety on productivity. The production function was estimated in the logarithmic form for the pooled sample of rice farmers $\left(\mathrm{P}_{\mathrm{II}}\right)$ and separately for the adopters $(\mathrm{A})$ and non-adopters (NA). The pooled sample of the rice farmers comprised the combined datasets of both the adopters and the nonadopters. The production functions have the following forms:

$$
\begin{aligned}
\operatorname{In} Y_{N A} & =\operatorname{In} \alpha_{1}+a_{1} \operatorname{In} S_{1}+a_{2} \operatorname{In} L d_{2}+a_{3} \operatorname{In} F_{3}+a_{4} \operatorname{In} H_{4} \\
& +a_{5} \operatorname{In} L_{5}+a_{6} \operatorname{In} A_{6}+a_{7} \operatorname{In} E_{7}+u \\
\operatorname{In}_{A} & =\operatorname{In} \alpha_{1}+b_{1} \operatorname{In} S_{1}+b_{2} \operatorname{In} L d_{2}+b_{3} \operatorname{In} F_{3}+b_{4} \operatorname{In} H_{4} \\
& +b_{5} \operatorname{In} L_{5}+b_{6} \operatorname{In} A_{6}+b_{7} \operatorname{In} E_{7}+u \\
\operatorname{InY}_{P_{I}} & =\operatorname{In} \alpha_{1}+c_{1} \operatorname{In} S_{1}+c_{2} \operatorname{In} L d_{2}+c_{3} \operatorname{In} F_{3}+c_{4} \operatorname{In} H_{4} \\
& +c_{5} \operatorname{In} L_{5}+c_{6} \operatorname{In} A_{6}+c_{7} \operatorname{In} E_{7}+u \\
& \\
\operatorname{In} Y_{P_{I I}} & =\operatorname{In} \alpha_{1}+d \operatorname{In} S_{1}+d_{2} \operatorname{InLd}_{2}+d_{3} \operatorname{In} F_{3}+d_{4} \operatorname{In} H_{4} \\
& +d_{5} \operatorname{InL}_{5}+d_{6} \operatorname{InA}_{6}+d_{7} \operatorname{In} E_{7}+d_{8} D V_{1}+u
\end{aligned}
$$

where:

$Y \quad=$ Rice output $(\mathrm{kg})$;

$\alpha \quad=$ Total factor productivity;

$S \quad=$ Total quantity of seeds $(\mathrm{kg})$;

$L d=$ Cultivated area (ha);

$F \quad=$ Total quantity of fertiliser $(\mathrm{kg})$;

$H \quad=$ Total quantity of herbicide $(l)$;

$L \quad$ =Labour (person-days);

$A \quad=$ Farmer's age (years);

$E \quad=$ Farmer's education (years of formal education);

$D V=$ Dummy variable for the improved rice variety;

$U \quad=$ Error term 
However, before estimating the production functions, the null hypothesis of parameter stability (i.e., no structural change) was empirically tested. Also, the hypothesis that the technical change from the introduction of the improved variety was of the neutral type was tested. These two hypotheses were tested using the F-test. Following Gujarati (2004), the F-test is specified as:

$$
F=\frac{\left(R S S_{R}-R S S_{U R}\right) / k}{\left(R S S_{U R}\right) /\left(n_{1}+n_{2}-2 k\right)} \sim F_{\left[k,\left(n_{1}+n_{2}-2 k\right)\right]}
$$

$$
\begin{array}{ll}
\text { where: } & \\
\mathrm{SSE}_{\mathrm{R}} & =\text { Restricted residual sum of squares for the } \\
& \text { pooled regression; } \\
\mathrm{SSE}_{\mathrm{UR}} & =\text { Unrestricted residual sum of squares for the } \\
& \text { regression of the adopters and non-adopters; } \\
\mathrm{k} & =\text { Number of estimated parameters including } \\
& \text { the intercept; } \\
\mathrm{n}_{1} & =\begin{array}{l}
\text { e Number of observations for the regression } \\
\mathrm{n}_{2}
\end{array} \\
& \begin{array}{l}
\text { equation of the adopters; } \\
\text { e Number of observations for the regression }
\end{array} \\
& \text { equation of non-adopters. }
\end{array}
$$

The structural break test provides the justification for estimating equations (1) and (2). However, to capture the impact of the improved rice variety on productivity, a varietal dummy variable was introduced into the pooled production function $\left(\mathrm{P}_{\mathrm{II}}\right)$. The use of the pooled regression with a dummy variable for productivity analysis has both theoretical and empirical support (Shideed and Saleem, 2005; Gujarati, 2004; Lin, 1994).

\section{Results and Discussions}

\section{Descriptive Statistics of the Variables Used in the Model}

Table 1 presents the mean and standard deviations of the variables used for the Cobb-Douglas production functions. The average farm size for both the adopters and the non-adopters was less than one hectare. This indicated that the rice farmers were predominantly smallholder farmers. The non-adopters reported higher seeding rates $(168.37 \mathrm{~kg})$ and volumes of herbicides $(11.57 \mathrm{l})$, compared with the adopters $(105.58 \mathrm{~kg}$ and $7.89 l$, respectively). The high demands for seed for the production of the unimproved variety could be because of the use of poor quality seeds, which have low germination rates. Moreover, the average quantities of fertiliser (594.64 kg) and labour (250.49 person-days) were higher for the adopters than the non-adopters $(391.99 \mathrm{~kg}$ and 227.40 person-days, respectively). This suggested that the production of the improved rice variety was very responsive to fertiliser and was labor-intensive. The output of rice was also higher for the adopters compared to the non-adopters; indicating that the improved rice variety had higher yield advantages compared with the unimproved varieties. The average output of the improved variety is consistent with the range of outputs reported by Kijima et al. (2006), JICA (2006) and Zenna et al. (2008).

\section{Hypotheses Tests on the Data}

A number of diagnosis tests were performed on the data before the model was analyzed. These were multicollinearity, normality test, and stability tests. Multicollinearity was tested using variance inflation factor and the results suggested that none of the explanatory variables exceeded the threshold value of 10 . Thus, multicollinearity was not a problem in the data. Test for normality of the residuals for all the estimated production functions revealed that the residuals were normally distributed. The production functions were estimated using heteroscedasticity-corrected approach to correct for the possible heteroscedasticity problem in the data.

A stability test was conducted using the Chow test to test the hypothesis that the intercept and slope coefficients are different for the adopters and non-adopters. This test equally sought to determine whether the technical change resulting from the introduction of the improved rice variety was of the neutral type or non-neutral type. The analysis of variance yielded an F-ratio of 8.159 with 8 and 192 degrees of freedom and statistically significant at $1 \%$ level. Therefore, the null hypothesis was rejected in favour of the alternate hypothesis. The results indicated that structural change existed in the production functions for the adopters and non-adopters. This implied that the technical change attributed to the introduction of the improved rice variety was not of the neutral type. That is, the hypothesis that output elasticities with respect to the various inputs were not the same in separate regressions for the adopters and non-adopters, if the constant terms in the two regressions were allowed to differ was rejected. Hence, this study estimated separate production functions for both the adopters and the non-adopters. However, the study used the dummy variable approach to capture the impact of the improved rice variety on productivity. Shideed and Saleem (2005) and Lin (1994) had justified the use of the dummy variable approach in measuring the impact of a qualitative variable on a quantitative outcome.

\section{Impact of the Improve Rice Variety on Productivity}

Output elasticities from the Cobb-Douglas production functions of the non-adopters and adopters are presented in Table 2. The explanatory powers $\left(\mathrm{R}^{2}\right)$ of the various production functions are $0.701,0.770$, and 0.720 for the adopters, non-adopters and pooled (II) production functions, respectively. The results suggested that the three models generally fit the data well at the $1 \%$ significance level. This implied that the variations in the (log of) production were explained by $70 \%$ to $72 \%$ of the (logs) of all the explanatory variables, respectively, in all the production functions. Further, the output elasticities satisfied priori expectations.

For the non-adopters, the results indicated that the herbicide, seed, land, and fertiliser were statistically significant. The output elasticities of these variables were consistent with the expected signs and economic logic. For instance, the output elasticities of seed, land, fertiliser, and herbicide were 0.294, 0.528, 0.046, and 0.105, respectively. In other words, holding other factors 
constant, a $1 \%$ increase in seeding rate was associated with an average of about $0.3 \%$ increase in rice production. Similarly, on the average, a $1 \%$ increase in total cultivated land led to about $0.5 \%$ increase in production, holding all other factors constant. Moreover, holding all other factors constant, a $1 \%$ increase in the use of fertiliser led, on the average, to about $0.5 \%$ increase in production. Overall, land, seed, herbicide, and fertiliser were the major determinants of the production of the unimproved rice variety in the two municipalities. The low impact of fertiliser on production could be due to the lack/delay/inadequacy of fertiliser application among the non-adopters. These results are consistent with past studies of Abdullahi (2012), and Resmi et al. (2013) who reported similar findings.

Table 1 Mean and Standard Deviations of Variables for the Cobb-Douglas Model.

\begin{tabular}{l|ccc}
\hline \multicolumn{1}{c|}{ Variables } & Non-Adopters & Adopters & Pooled \\
\hline Production (kg) & $4345.57(3113.04)$ & $5348.39(3717.62)$ & $4851.80(3514.29)$ \\
Seed (kg) & $168.37(113.03)$ & $105.58(73.23)$ & $136.67(99.90)$ \\
Land (ha) & $0.95(0.64)$ & $0.74(0.56)$ & $0.84(0.61)$ \\
Fertiliser (kg) & $391.99(373.69)$ & $594.64(563.71)$ & $494.29(488.65)$ \\
Herbicide (l) & $11.57(12.55)$ & $7.89(6.84)$ & $9.71(10.22)$ \\
Labour (person-days) & $227.40(266.48)$ & $250.49(203.35)$ & $263.81(236.54)$ \\
Age (years) & $46.54(13.37)$ & $49.51(13.06)$ & $48.04(13.27)$ \\
Education (years) & $2.60(4.12)$ & $4.20(5.40)$ & $3.41(4.87)$ \\
\hline
\end{tabular}

Note: Values in parentheses indicate standard errors.

Table 2 Estimated Production Functions for the Rice Farmers.

\begin{tabular}{|c|c|c|c|c|}
\hline Variables & Non-Adopters & Adopters & Pooled I & Pooled II \\
\hline Constant & $6.428 * * *(0.895)$ & $7.410 * * *(1.072)$ & $6.978 * * *(0.790)$ & $7.123 * * *(0.712)$ \\
\hline Seed & $0.294 * *(0.127)$ & $0.400 * *(0.164)$ & $0.067(0.110)$ & $0.256^{* *}(0.104)$ \\
\hline Land & $0.528 * * *(0.0 .191)$ & $0.610 * * *(0.196)$ & $0.691 * * *(0.141)$ & $0.679 * * *(0.0 .133)$ \\
\hline Labour & $-0.057(0.0 .067)$ & $-0.142 * * *(0.039)$ & $-0.008(0.052)$ & $-0.095 *(0.049)$ \\
\hline Fertiliser & $0.046 * * *(0.015)$ & $0.037 * * *(0.013)$ & $0.0845 * * *(0.011)$ & $0.053 * * *(0.0 .012)$ \\
\hline Herbicide & $0.105^{*}(0.063)$ & $0.058 * *(0.027)$ & $0.065(0.040)$ & $0.071 * *(0.030)$ \\
\hline Age & $0.072(0.144)$ & $-0.046(0.093)$ & $0.165(0.102)$ & $0.001(0.092)$ \\
\hline Education & $0.001(0.040)$ & $0.057 * *(0.029)$ & $0.059 * *(0.027)$ & $0.029(0.0 .023)$ \\
\hline $\mathrm{DV}_{1}$ & - & - & - & $0.457 * * *(0.063)$ \\
\hline No. obs. & 103 & 105 & 208 & 208 \\
\hline $\mathrm{R}^{2}$ & 0.701 & 0.770 & 0.718 & 0.720 \\
\hline F-value & $31.856 * * *$ & $46.339 * * *$ & 72.923 & $63.807 * * *$ \\
\hline JB test & 3.435 & 0.182 & 8.623 & 3.075 \\
\hline
\end{tabular}

Note: $* \mathrm{P}<0.10, * * \mathrm{P}<0.05, * * * \mathrm{P}<0.001 ; \mathrm{JB}$ : Jarque-Bera test of normality. Pooled I and II: Polled production function without and with dummy variable, respectively. Values in parentheses indicate standard errors. $\mathrm{DV}_{1}$ : Dummy variable for improved rice variety.

The output elasticities for the adopters indicated that the statistically significant variables were seed, land, labour, fertiliser, herbicide, and education. All the significant variables had their expected signs, except labour. Seed, land, and labour had output elasticities of $0.400,0.610$, and -0.142 , respectively. Therefore, the land was the most important factor in the production of the improved rice variety. On the average, a $1 \%$ increase in the cultivated land area led to about $0.6 \%$ increase in total production, holding all other factors constant. Moreover, a $1 \%$ increase in seeding rate, holding all other factors constant, led on the average to $0.4 \%$ increase in total production. The output elasticity of labour was negative and thus suggested that holding all other factors constant, a $1 \%$ increase in the labour input leads on the average to about $0.1 \%$ decrease in production; depicting diminishing marginal returns to labour. Thus, there was excessive use of labour among the adopters, partly because of its labourintensive nature. That is, considering the fact that the improved rice variety was labour demanding, the adopters increased the use of labour to the point where the additional use of labour yielded smaller or diminishing increase in the output of rice. Hence, labour saving technologies should be provided.

The output elasticity of the fertiliser input was 0.037 , indicating that, holding all other inputs constant, a $1 \%$ increase in fertilization would result, on the average, in about a $0.04 \%$ increase in the production of the improved rice. The low effect of fertilization on production is due to the use of fertiliser below its recommended level. Similarly, ceteris paribus, a $1 \%$ increase in the application of herbicides would on the average increase the production of the improved rice by about $0.06 \%$. Finally, the output elasticity of education was 0.057 ; suggesting that an additional year of education of the adopters would lead to about $0.06 \%$ increase in production, all other factors held constant. The result is consistent with that of Abdullahi (2012), Balakrishna (2012), Basavaraja et al. (2008), and Resmi et al. (2013).

In the Pooled II model, the varietal intercept dummy, i.e., $\mathrm{DV}_{1}$ was used to measure the impact of the improved rice variety on the productivity of rice. For this model, the 
data were pooled, i.e., the data for the adopters and the non-adopters were combined and the $\mathrm{DV}_{1}$ introduced. The estimated pooled regression model (Pooled II) showed that seed, land, labour, fertiliser, herbicide and the varietal dummy variable $\left(\mathrm{DV}_{1}\right)$ were statistically significant (Table 2). All variables had their expected signs expect labour. The results suggested that a percentage increase in seeding rate, land, fertiliser, and herbicide would, on the average, lead to a corresponding percentage increase in the output, ceteris paribus. However, a percentage increase in the lab or input would, on the average, lead to the same decrease in production. The study hypothesized that the improved rice variety had a significantly higher impact on rice productivity, compared to the unimproved rice variety. The output elasticity of the varietal dummy variable measures the shift in the intercept of the production function due to the improved rice variety. The output elasticity for this variable was 0.457 and was statistically significant at the $1 \%$ level. This suggested that the improved rice variety increased total factor productivity in the study area by as much as $46 \%$, compared to the unimproved rice variety. However, given that the shift in the production function was not of the neutral type, it implied that the improved rice variety did not give a higher output per unit of each input. That is, the increase in output was due to non-neutral technical change. These results are consistent with the findings reported by Tiamiyu et al. (2009), Arega and Ousmane (2009) and Adegbola et al. (2006).

In general, the output elasticities of seed and land were higher for the adopters compared to the nonadopters. The positive effect of land on output refuted the commonly held inverse relationship between land size and output. Similarly, the positive effect of seed on production underscored the importance of certified seed in rice production. In contrast, non-adopters reported higher output elasticities for fertiliser and herbicide. The low effect of fertiliser on the production of the improved seed could be due to the diversion of the fertiliser supposedly meant for the improved rice variety into the production of other crops. This view was further reenforced by the farmers' assertion that the improved rice variety gave higher yield advantages even with minimum fertiliser application. The significant and positive effect of the variable inputs is consistent with Balakrishna (2012), Basavaraja et al. (2008), Kumar and Singh (2013) as well as Shideed and Salem (2005).

The sum of the output elasticities for the variable inputs gave $0.916,0.963$, and 0.964 for the adopters, nonadopters, and pooled (II) production functions, respectively. This suggested that the rice farmers during the 2012 production season experienced diminishing returns to scale. However, there was no evidence to suggest that these values are statistically different from one. Hence, a linear equality restriction was tested for the Cobb-Douglas production function. The null hypothesis was that the sum of the output elasticities of the CobbDouglas production function sum to one. The F-test reported $F(1,95)=0.006$ with p-value of $0.937 ; F(1,97)$ $=0.682$ with $\mathrm{p}$-value of 0.411 and $\mathrm{F}(1,199)=0.124$ with $\mathrm{p}$-value of 0.725 for the adopters, non-adopters, and pooled production functions, respectively. Therefore, the hypothesis of constant returns to scale was not rejected. The finding suggested that the data were consistent with the hypothesis of constant returns to scale (and not diminishing returns to scale). This implied that the choice of the Cobb-Douglas production model was appropriate for the data. Therefore, rice production in the two municipalities during the 2012 major production season was characterized by constant returns to scale. In other words, a one percent increase in all inputs leads to the same percentage increase in output, all other factors held constant. There was evidence that rice production could be increased through greater use of cultivated land, seeds, fertiliser, and herbicides.

\section{Conclusions}

In this study, we investigated the impact of the improved rice variety on the productivity of rice. The study has established that the improved rice variety has a superior yield advantage over the unimproved rice variety. Technical change attributed to the introduction of the improved rice variety was of the non-neutral type, i.e., it was neither labour saving nor cost saving. The productivity of rice had increased by $46 \%$ with the introduction of the improved rice variety. Among the adopters, productivity increases were driven by seed, land, fertiliser, herbicide and education. For the nonadopters, productivity gains were due to seed, land, herbicide and fertiliser. Our demonstration that the improved rice variety had increased productivity implies that productivity gains can be increased through greater use of cultivated land, seeds, fertiliser, and herbicides. The challenge for policy makers is to simultaneously promote the use of improved rice varieties and their recommended inputs among rice farmers, remove the impediments that prevent greater use of modern inputs, and provide credits facilities to enhance the timely purchase and use of productive resources in rice production. Overall, it can be concluded improved rice varieties could lead to considerable productivity gains it they are promoted alongside recommended inputs and tied with an effective input supply and education programs to enhance efficient use of inputs.

\section{Acknowledgements}

Special thanks go to the Ghana Strategy Support Program of the International Food Policy Research Institute for providing funding for the research leading to this paper. The authors owe a debt of gratitude to the rice farmers in the two municipalities who made the empirical findings of this study possible.

\section{References}

Abdullahi A. 2012. Comparative economic analysis of rice production by adopters and non-adopters of improved varieties among farmer in Paikoro Local Government Area of Niger State. Niger. J. Basic Appl. Sci., 20(2): 146-151. Available from: http://www.ajol.info/index.php/njbas/index [Assessed 4 October 2016]. 
Adégbola PY, Arouna A, Diagne A, Souléïmane AA. 2006. Evaluation de l'impact économique des nouvelles variétés de riz NERICA au Bénin: Évidence avecles modèles basés sur l'approche contre factuel. Paper presented at the First Africa Rice Congress, Dares Salaam.

Adewuyi SA. 2006. Resource use productivity of rural farmers in Kwara State, Nigeria. Int. J. Agri. Sci. Sci. Environ. Technol., 1(1): 20-31. DOI: 10.5829/idosi.aejaes.2013.13.09.11234

Arega DA, Ousmane C. 2009. The impact of agricultural research on productivity and poverty in sub-Saharan Africa. Food Policy, 34: 198 - 209. DOI: 10.1016/j.foodpol.2008.10.014.

Babbie ER. 2007. The practice of social research, $13^{\text {th }}$ ed., Belmont, California: Thompson Learning. ISBN-10: 1133049796.

Balakrishna A. 2012. Economics of Bt cotton in India. J. Dev. Agric. Econ., 4(5): 119 - 124. DOI: 10.5897/JDAE11.095.

Basavaraja H, Mahajanashetti SB, Sivanagaraju P. 2008. Technological change in paddy production: A comparative analysis of traditional and SRI methods of cultivation. Indian J. Agric. Econ., 63(4), 629-640. Available from: https://www.environmentportal.in/files/Indian\%20Journal\%20O f\%20Agr\%20Eco\%203.pdf [Assessed 4 October 2016].

Dibba L. 2010. Estimation of NERICA adoption rates and impact on productivity and poverty of the small-scale rice farmers in The Gambia. Unpublished master's thesis). Kumasi, Ghana: Department of Agricultural Economics, Agribusiness, and Extension, Kwame Nkrumah University of Science and Technology. Available from: https://www.ir.knust.edu.gh/ bitstream/123456789/222/1/Lamin\%20Dibba's\%20Thesis.pdf [Assessed 4 October 2016].

Fan S, Hazell P, Thorat S. 2000. Government spending, growth and poverty in rural India. Am. J. Agric. Econ., 82: 1038-1051. Available from: http://econpapers.repec.org/article/oupajagec/ v_3a82_3ay_3a2000_3ai_3a4_3ap_3a1038-1051.htm [Assessed 6 October 2016].

FAO. 2004. Food outlook No. 4. Rome, Italy: Food and Agriculture Organization of the United Nations.

FAO. 2006. World agriculture towards 2030/2050: Interim report. Rome, Italy: Food and Agriculture Organization of the United Nations.

Government of Ghana. 2009. Budget statement and economic policy for 2010. Available from: http://www.ghana.gov.gh/.../budgetstatement/514-budget-statemen. [Assessed 4 March 2012].

Gujarati DN. 2004. Basic econometrics. $4^{\text {th }}$ ed., New York: The McGraw-Hill Companies. ISBN: 978-3-319-07662-1.

Hussain I, Perera IR. 2004. Improving agricultural productivity through integrated service provision with public. Private-sector partnership. Working Paper 66. Columbia, Sri Lanka: International Water Management Institute.

JICA. 2006. Proceedings of JAICAF/WARDA/JICA joint seminar on NERICA dissemination in Africa. Accra, Ghana: JICA.

Kijima Y, Sserunkuuma D, Otsuka K. 2006. How revolutionary is the NERICA revolution? Evidence from Uganda. Dev. Econ., 44(2): 252-267. DOI: 10.1111/j.1746-1049.2006.00016.x.

Kumar H, Singh R. 2013. Economic analysis of freshwater aquaculture production: A comparative analysis of different production systems. Russ. J. Agric. Soc.-Econ. Sci., 1(13): $49-$ 55. Available from: https://ideas.repec.org/a/scn/ 031261/14105162.html [Assessed 8 October 2016].
Lin, J. Y. 1994. Impact of hybrid rice on input demand and productivity. Agric. Sys., 10, 153-164. DOI:10.1016/01695150(94)90004-3.

Ministry of Food and Agriculture. 2009. The Republic of Ghana national rice development strategy (NRDS) (Draft). Accra: Ministry of Food and Agriculture. Available from: https://www.jica.go.jp/english/our_work/thematic_issues/agricu ltural/pdf/ghana_en.pdf [Assessed 10 October 2016].

Nin A., Channing A. Paul VP. 2003. Is agricultural productivity in developing countries really shrinking? New evidence using a modified nonparametric approach. J. Dev. Econ., 71, 395-415.

O'Donnell CJ. 2010. Measuring and decomposing agricultural productivity and profitability change. Aust. J. Agri. Resour. Econ., 54: 527-560. DOI: 10.1111/j.1467-8489.2010.00512.x.

Oni O, Nkonya E, Pender J, Phillips D, Kato E. (2009). Analyzing drivers of food crop productivity in Nigeria. J. Econ. Rural Dev. 18(1): 36-45. Available from: https://www.ageconsearch. umn.edu/bitstream/147904/2/Dr.\%20Oni.pdf [Assessed 4 October 2016].

Organization for Economic Cooperation and Development [OECD]. 2006. Promoting pro-poor growth: Agriculture, DAC guidelines and reference series. Paris: OECD. Available from: https://www.oecd.org/dac/povertyreduction/43514582.pdf [Assessed 4 October 2016].

Poulton C, Kydd J, Dorward A. 2006. Overcoming market constraints on pro-poor agricultural growth in Sub-Saharan Africa. Dev. Policy Rev., 24(3): 243-277. Available from: https://www.citeseerx.ist.psu.edu/viewdoc/download?doi=10.1. 1.572.1422\&rep=rep1 [Assessed 4 October 2016].

Resmi P, Kunnal LB, Basavaraja H, Bhat ARS, Handigol JA, Sonnad JS. 2013. Technological change in black pepper production in Idukki district of Kerala: A decomposition analysis. Karnataka J. Agr. Sci., 26(1): 76-79. Available from: https://www.14.139.155.167/test5/index.php/kjas/article/view/6 761/6981 [Assessed 4 October 2016].

Shideed KH, Salem KK. 2005. The impact of barley varietal technology in Iraq. In: Shideed KH, Mourid ME. Adoption and impact assessment of improved technologies in crop and livestock production systems in the WANA Region. Eds., Aleppo, Syria: International Centre for Agricultural Research in the Dry Areas. Pp: 55-72. ISBN: 92-9127-180-3. Available from: https://www.impact.cgiar.org/pdf/297.pdf [Assessed 4 October 2016].

Tiamiyu SA, Akintola JO, Rahji MAY. 2009. Technology adoption and productivity difference among growers of New Rice for Africa in Savannah Zone of Nigeria. Tropicultura, 27(4), 193197. Available from: www.tropicultura.org/text/v27n4/193.pdf [Assessed 4 October 2016].

World Bank. 2008. World Development Report 2008: Agriculture for development. Washington, DC: World Bank. ISBN: 978- 0 8213-7297-5.

Zenna NS., Gebre-Tsadik Z, Berhe T. 2008. Moving up in Ethiopia. Ethiopia: International Rice Research Institute. Available from: http://irri.org/knowledge/publications/ricetoday/features/features-africa/moving-up-in-ethiopia. [Assessed 4 October 2016]. 